Jurnal Ilmiah Farmasi (Scientific Journal of Pharmacy) 17(2) Agustus-Desember 2021, 197-209

ISSN: $1693-8666$

available at http://journal.uii.ac.id/index.php/JIF

\title{
Review: Neuroprotective effect of herbal plant extracts against Parkinson's disease
}

\section{Review: Efek pelindung saraf ekstrak tanaman herbal terhadap penyakit Parkinson}

\author{
Syifa Fitriyanda Salsabila ${ }^{1}$, Widhya Aligita $^{1 *}$, Yani Mulyani ${ }^{1}$ \\ 1Fakultas Farmasi, Universitas Bhakti Kencana, Bandung \\ *Corresponding author: widhya.aligita@bku.ac.id
}

\begin{abstract}
Background: Parkinson's disease (PD) is a progressive neurodegenerative disorder caused by the loss of dopaminergic neurons and the exist of $\alpha$-synuclein aggregates in the substantia nigra pars compacta (SNpc). Among the various types of neuroprotective therapy, natural products are potential therapeutic agents for PD.

Objective: The aim of this study is to describe the neuroprotective effect of herbal plant extracts against Parkinson's Disease (PD).

Method: The search strategy was carried out on electronic databases, namely Google Scholar, ScienceDirect, and PubMed ${ }^{\circledR}$. There are 111 scientific journals that have been filtered into 20 scientific journals which are international journals published in the last 5 years (2015-2020). The keywords used include "Parkinson's Disease", "Neuroprotective Effects", "Neuroprotection", "Plant Extracts", "Natural Products" and "Parkinson's Disease Model".

Results: Several experimental studies have shown the neuroprotective ability of various plant extracts to protect against neurotoxicity, through several neuroprotective pathways including antioxidant activity, anti-inflammatory activity, and antiapoptotic activity.

Conclusion: Herbal plant extracts have been shown to have strong neuroprotective effects, making them as potential drug candidates for prevention or treatment of Parkinson's Disease (PD). There are Mucuna pruriens, Centella asiatica, Camellia sinensis, Ginkgo biloba, and Uncaria rhynchophylla.

Keywords: Parkinson's Disease (PD), neuroprotective, extract.
\end{abstract}

\section{Intisari}

Latar belakang: Penyakit Parkinson adalah gangguan neurodegeneratif progresif yang disebabkan oleh hilangnya neuron dopaminergik dan adanya agregat yang mengandung $\alpha$-synuclein di substansia nigra pars compacta. Diantara berbagai jenis terapi pelindung saraf, produk alami merupakan agen terapi yang potensial untuk PD.

Tujuan: Untuk menggambarkan efek pelindung saraf ekstrak tanaman herbal terhadap penyakit Parkinson.

Metode: Strategi pencarian dilakukan pada database elektronik yaitu Google Scholar, ScienceDirect, dan PubMed ${ }^{\circledR}$. Terdapat 111 Jurnal ilmiah yang telah di saring menjadi 20 jurnal ilmiah dan merupakan jurnal internasional yang diterbitkan 5 tahun terakhir (2015-2020). Kata kunci yang digunakan diantaranya "Parkinson's Disease", "Neuroprotective Effects", "Neuroprotection", "Plant Extracts", "Natural Products" dan "Parkinson's Disease Model".

Hasil: Beberapa studi eksperimen menunjukkan kemampuan pelindung saraf dari berbagai ekstrak tanaman untukmelindungineurotoksisitas, melalui beberapa jalur pelindung saraf diantaranya aktivitas antioksidan, aktivitas antiinflammmasi, dan aktivitas antiapoptosis.

Kesimpulan: Ekstrak tanaman herbal terbukti memiliki efek pelindung saraf yang kuat sehingga menjadikannya sebagai calon obat potensial untuk terapi pencegahan atau pengobatan penyakit Parkinson, diantaranya ekstrak tanaman Mucuna pruriens, Centella asiatica, Camellia sinensis, Ginkgo 
198 | Salsabila, dkk /Jurnal Ilmiah Farmasi (Scientific Journal of Pharmacy) 17(2) Agustus-Desember 2021, 198-210

biloba, dan Uncaria rhynchophylla.

Kata kunci: Penyakit Parkinson. pelindung saraf, ekstrak

\section{Pendahuluan}

Penyakit Parkinson/Parkinson's Disease (PD) merupakan salah satu penyakit neurodegeneratif yang umum dan terdapat di seluruh dunia (Tjay \& Rahardja, 2015). Penyakit neurodegeneratif merupakan suatu kondisi dimana sel-sel otak secara progresif kehilangan kemampuannya untuk menghasilkan neurotransmitter (Jayanthi \& Vijayalakshmi, 2018). PD disebabkan oleh hilangnya neurotransmiter dopamin dan adanya agregat yang mengandung $\alpha$-synuclein di substansia nigra pars compacta (SNpc) (Wang et al., 2015a). Dopamin dihasilkan oleh sel-sel saraf di otak, bila sel saraf tersebut rusak maka produksi dopamin akan berkurang sehingga kemampuan otak untuk mengatur dan mengkoordinasi gerakan akan terganggu (Ardhianta et al., 2019). Mekanisme yang menyebabkan hilangnya neurotransmitter dopamin dan penyebab gejala motorik PD masih belum diketahui secara pasti (Segura-Aguilar et al., 2014). Namun ada beberapa faktor penyebab PD diantaranya faktor lingkungan, genetika, usia, dan faktor obat-obatan (Bais et al., 2015). Bukti terbaru menunjukkan bahwa stres oksidatif, aktivasi mikroglial, peradangan saraf, dan mekanisme apoptosis terlibat dalam patologi utama PD (Pringsheim et al., 2014).

Gejala klinis utama PD adalah tremor, kekakuan otot, diskinesia, dan ketidakseimbangan postur tubuh dan Gerakan (H. Zhang et al., 2017). Dibandingkan dengan lansia normal, pasien lansia yang menderita PD telah dilaporkan memiliki kualitas hidup yang sangat rendah, karena berhubungan dengan depresi, insomnia, dll (Marumoto et al., 2019). Sehingga secara pasti PD sangat mengganggu aktivitas sehari-hari (Zhang et al., 2017). Tanpa pengobatan setelah 5-10 tahun PD akan menyebabkan penderita tidak berdaya (akinetic state) karena penderita tidak dapat lagi merawat dan mengontrol diri sendiri (Tjay \& Rahardja, 2015).

Standar emas pengobatan PD adalah terapi dengan levodopa (Mouchaileh \& Hughes, 2020). Umumnya terdiri dari pemberian levodopa dan biperiden, karena kedua obat tersebut dapat mengurangi perkembangan penyakit dan juga gejala PD (da Costa et al., 2017). Strategi pengobatan alternatif perlu dikembangkan karena penggunaan jangka panjang levodopa menuntut peningkatan dosis yang progresif dan pasti menghasilkan berbagai komplikasi (Sandhu \& Rana, 2013). Obat-obatan sintetis PD dapat menimbulkan efek merugikan seperti 
199 | Salsabila, dkk /Jurnal Ilmiah Farmasi (Scientific Journal of Pharmacy) 17(2) Agustus-Desember 2021, 198-210

kesulitan tidur akibat eksitasi, kerusakan fungsi hati, kerusakan ginjal, halusinasi, depresi dan diskinesia, jika digunakan terus menerus dan pada dosis berlebih (Sandhu \& Rana, 2013).

Salah satu jenis terapi yang paling potensial dalam pengobatan PD ialah terapi dengan bahan alam (Li et al., 2019). Sebagai sumber daya, bahan alam mampu memberikan efisiensi dalam penemuan agen terapi baru terhadap pengobatan PD (Zhang et al., 2017). Sebagai terapi tambahan baru, bahan alam telah banyak dievaluasi untuk mengidentifikasi potensi sinergisnya dalam kombinasi dengan levodopa (Ahn et al., 2017). Beberapa tanaman obat, senyawa aktif dan ekstraknya secara positif dapat memberikan efek pelindung saraf terhadap kematian sel saraf (Du et al., 2010), sehingga terjadi peningkatan minat terhadap obat herbal sebagai pengobatan untuk PD (Li et al., 2013). Oleh karena itu, review artikel ini akan membahas mengenai ekstrak tanaman herbal yang terbukti memiliki efek pelindung saraf terhadap PD.

\section{Metode}

Pencarian jurnal ilmiah yang digunakan sebagai referensi dalam artikel review ini dilakukan pada database elektronik terindeks yaitu Google Scholar, ScienceDirect, dan PubMed ${ }^{\circledR}$. Kata kunci yang digunakan untuk pencarian diantaranya "Parkinson's Disease", "Neuroprotective Effects". "Neuroprotection", "Plant Extracts", "Natural Products", dan "Parkinson's Disease Model".

Jurnal ilmiah yang telah didapat kemudian diskrining berdasarkan kata kunci, judul, abstrak, dan isi teks secara keseluruhan. Kriteria inklusi pada studi ini yaitu jurnal ilmiah internasional berbahasa Inggris yang diterbitkan tahun 2015-2020 (5 tahun terakhir) dan merupakan jurnal ilmiah hasil penelitian (original research articles) yang membahas mengenai efek pelindung saraf ekstrak tanaman herbal yang berpengaruh terhadap PD. Adapun kriteria eksklusi berupa jurnal ilmiah dengan studi yang dilakukan hanya in vitro saja dan tidak berfokus pada penelitian terhadap ekstrak tanaman. Setelah dilakukan proses skrining, didapatkan jurnal ilmiah yang relevan dengan penelitian ini sebanyak 20 jurnal dari Google Scholar $(n=10), \operatorname{PubMed} \circledast(n=6)$, dan ScienceDirect $(n=4)$. 


\section{Hasil dan pembahasan}

Patologi utama PD yang bertanggung jawab atas kematian neuron dopaminergik masih belum diketahui (Abushouk et al., 2017), namun terdapat kesepakatan umum dalam komunitas ilmiah bahwa mekanisme molekuler yang bertanggung jawab atas degenerasi neuron dopaminergik pada PD diantaranya disfungsi mitokondria, agregasi $\alpha$-synuclein, disfungsi dari degradasi protein, stresoksidatif dan peradangan pada saraf (neuroinflamasi) erat kaitannya dengan PD (Segura-Aguilar et al., 2014). Berbagai model hewan telah dikembangkan untuk evaluasi PD yang dihasilkan dengan menginduksi neurotoksin pada otak (Bais et al., 2015), di antaranya neurotoksin 6-hydroxydopamine (6-OHDA), 1-methyl-4-phenyl1,2,3,6-tetrahydropyridine (MPTP), rotenone (ROT), parakuat diklorida, lipopolisakarida, mangan, dll (Blesa et al., 2012; Klivenyi \& Vescei, 2011). PD menyebabkan efek yang sangat merugikan bagi penderitanya, sehingga berbagai studi diperlukan untuk mengetahui mekanisme perilaku dan neurokimia yang terlibat dalam PD (Kim et al., 2012; Zhang et al., 2015). Berbagai tanaman obat telah diuji selama bertahun-tahun, dan beberapa telah menunjukan hasil yang luar biasa (Suliman et al., 2016). Dari berbagai uji secara praklinis, telah diidentifikasi beberapa mekanisme yang mendasari efek pelindung saraf yang diamati dari tanaman obat, diantaranya mekanisme antioksidan, mekanisme antiinflamasi, dan mekanisme antiapoptosis (Abushouk et al., 2017).

Tabel 1. Hasil studi literatur ekstrak tanaman herbal

\begin{tabular}{|c|c|c|c|}
\hline Referensi & $\begin{array}{c}\text { Nama } \\
\text { Tanaman }\end{array}$ & $\begin{array}{c}\text { Bagian } \\
\text { Tanaman }\end{array}$ & Hasil \\
\hline $\begin{array}{l}\text { (Adi et al., } \\
\text { 2018) }\end{array}$ & $\begin{array}{l}\text { Mucuna } \\
\text { pruriens }\end{array}$ & Biji & - $\quad$ Neuron dopamin (DA) $\uparrow$ \\
\hline $\begin{array}{l}\text { (Bhangale \& } \\
\text { Acharya, } \\
\text { 2016) }\end{array}$ & Ficus religiosa & Daun & $\begin{array}{ll}\text { - } & \text { Kinerja motorik } \uparrow \\
\text { - } & \text { Kerusakan oksidatif } \downarrow\end{array}$ \\
\hline $\begin{array}{l}\text { (Khotimah et } \\
\text { al., 2015) }\end{array}$ & & & $\begin{array}{l}\text { - } \quad \text { Agregasi dan ekspresi } \alpha \text {-synuclein } \downarrow \\
\text { - } \quad \text { Motilitas dan neuron DA } \uparrow\end{array}$ \\
\hline $\begin{array}{l}\text { (Teerapattara } \\
\text { kan et al., } \\
\text { 2018) }\end{array}$ & $\begin{array}{l}\text { Centella } \\
\text { asiatica }\end{array}$ & Daun & 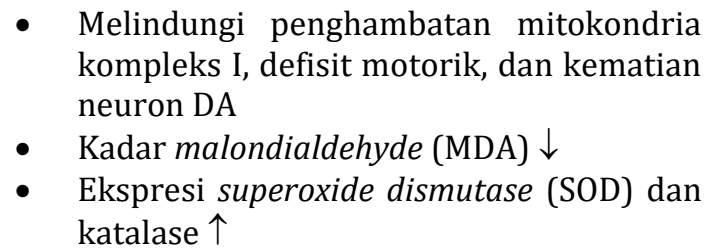 \\
\hline $\begin{array}{l}\text { (Sood et al., } \\
\quad 2020 \text { ) }\end{array}$ & $\begin{array}{l}\text { Epipremnum } \\
\text { aureum }\end{array}$ & Daun & $\begin{array}{l}\text { - Melemahkan peningkatan kadar } \\
\text { thiobarbituric acid reactive substance } \\
\text { (TBARS) } \\
\text { - } \text { Kadar glutathione (GSH) dan aktivitas }\end{array}$ \\
\hline
\end{tabular}




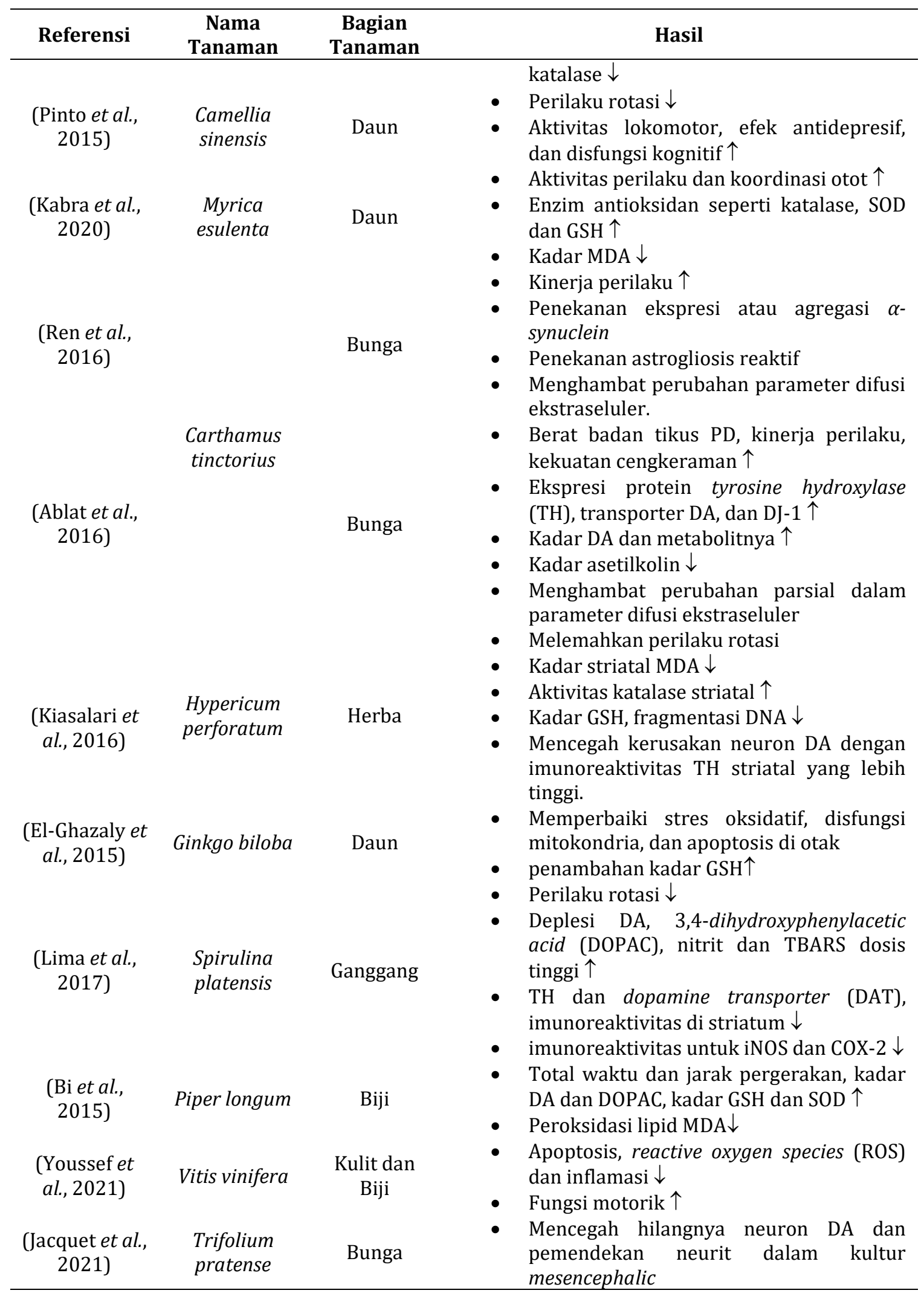




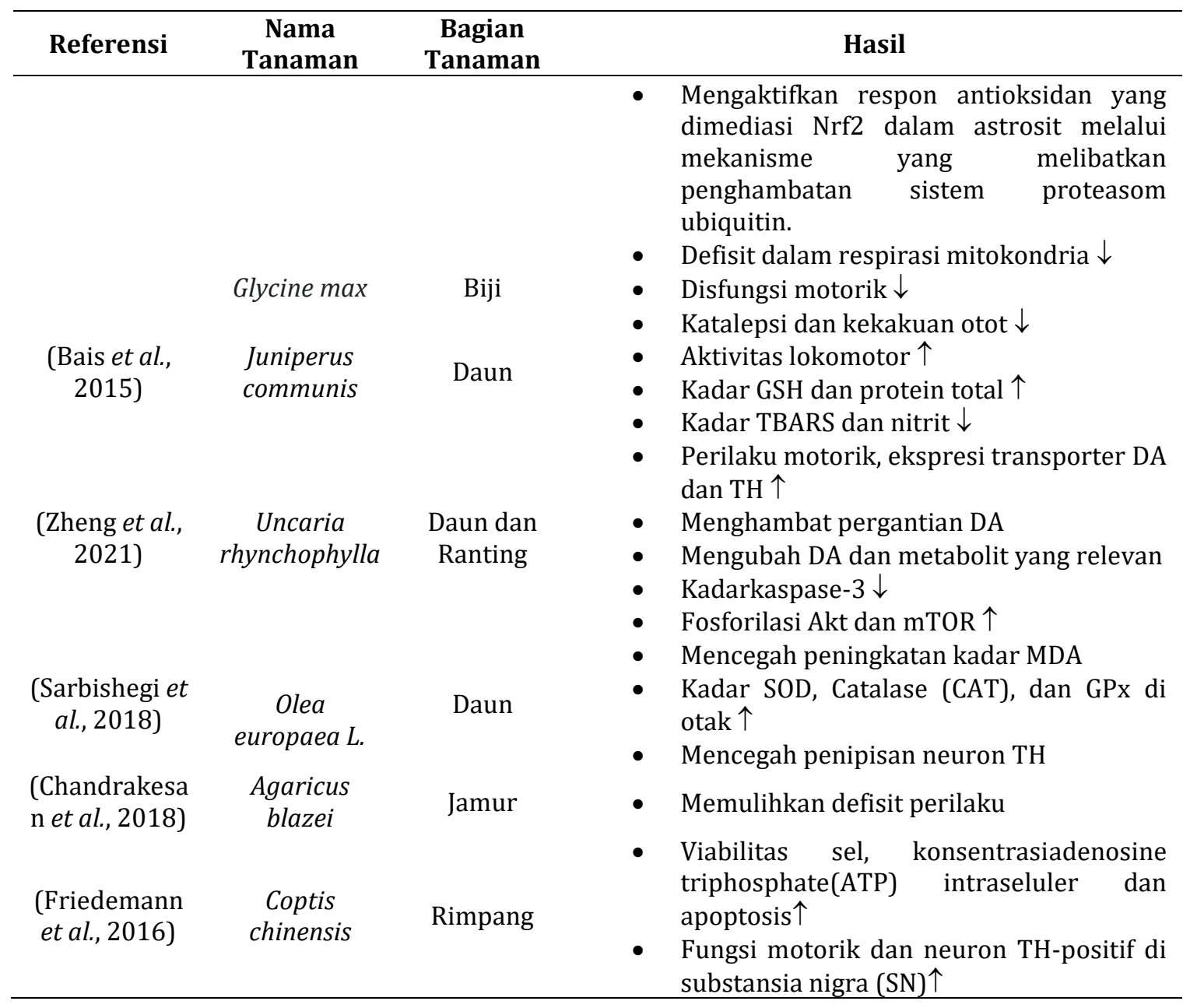

\subsection{Aktivitas antioksidan}

Tanaman obat yang memiliki khasiat sebagai antioksidan telah banyak dipelajari sebagai strategi pengobatan terhadap penyakit neurodegeneratif (Albarracin et al., 2012; Song et al., 2012). Stres oksidatif yang dihasilkan sebagai akibat dari disfungsi mitokondria terutama gangguan mitokondria kompleks-1 memainkan peran penting dalam patogenesis PD. Stres oksidatif diukur melalui penentuan kadar malondialdehyde (MDA), catalase (CAT), superoxide dismutase (SOD), dan glutathione (GSH) di jaringan otak (Bhangale \& Acharya, 2016). Pretreatment dengan antioksidan dapat menunda kematian neuronal (Essa et al., 2014). Biji koro benguk (Mucuna pruriens) (MP) memiliki aktivitas antioksidan dan pelindung saraf (Kasture et al., 2013). Ada lebih dari 50 zat yang terkandung dalam biji MP (Lieu et al., 2012). Hasil penelitian terdahulu menunjukan bahwa efek pelindung saraf biji MP pada model hewan PD berasal dari antioksidan alkaloid atau antioksidan lain seperti asam ursolat yang 
terkandung dalam biji MP (Yadav et al., 2016). Ekstrak n-Propanol dari biji MP yang direbus dan difermentasi dapat memberikan efek pelindung saraf yang lebih tinggi terhadap neuron dopamin daripada biji segar dalam model tikus PD (Adi et al., 2018).

Ekstrak teh hijau (Camellia sinensis) (CS), katekin, epikatekin dan epigalokatekin gallat, menunjukan efek pelindung saraf pada model hewan PD. Ekstrak teh hijau mencegah kerusakan neuron DA pada tikus yang diinduksi 6-OHDA di jalur nigrostriatal, diduga kuat karena aktivitas antioksidan dan antiinflamasinya (Pinto et al., 2015). Kombinasi ekstrak daun CS, akar Asparagus racemosus, dan biji MP (1: 1: 1) menunjukkan aktivitas antioksidan dan antiparkinson yang sangat signifikan pada uji katalepsi yang diinduksi haloperidol, uji hipolokomotor yang diinduksi reserpin dan uji Vacuous Chewing Movements (VCM) yang diinduksi takrin (Giri et al., 2020). Ekstrak lainnya yaitu Hypericum perforatum L. (St. John's wort) secara tradisional digunakan untuk berbagai gangguan penyakit, terutama depresi ringan sampai sedang. Gangguan depresi sering terjadi pada pasien dengan PD (Marsh, 2013). Telah dibuktikan bahwa ekstrak $H$. perforatum dan beberapa komponen utamanya memiliki kemampuan untuk melindungi saraf dari paparan neurotoksin, baik secara langsung, melalui mekanisme pelindung saraf, atau secara tidak langsung, melalui sifat antioksidan (Oliveira et al., 2016).

Ekstrak metanol dari daun pegagan (C. asiatica) memiliki senyawa bioaktif penting seperti asiaticoside yang memiliki sifat antiinflamasi dan antioksidan. Telah dilakukan uji pada model PD ikan zebra yang diinduksi ROT bahwa C. asiatica dapat meningkatkan kemampuan gerakan melalui adanya penurunan agregasi $\alpha$-synuclein dan stabilitas neurotransmiter dopamin (Khotimah et al., 2015). Efek antioksidannya dapat melindungi kematian neuron DA dan melindungi defisit motorik pada tikus yang diinduksi ROT (Teerapattarakan et al., 2018).

\subsection{Aktivitas antiinflamasi}

Faktor lain yang dapat berkontribusi pada hilangnya neuronal yang mendasari PD adalah inflamasi saraf yang selanjutnya meningkatkan reactive oxygen species (ROS) dan memperburuk PD. Respon inflamasi yang terkait dengan hilangnya sel di saluran nigrostriatal dopaminergik dan peran mekanisme imun, yang berhubungan dengan stres oksidatif, semakin diperhatikan sebagai faktor penting dalam patogenesis PD (Blandini, 2013). Peradangan kronis adalah ciri utama PD dan patologi neurodegeneratif ini tidak hanya 
204 | Salsabila, dkk /Jurnal Ilmiah Farmasi (Scientific Journal of Pharmacy) 17(2) Agustus-Desember 2021, 198-210

mencakup deregulasi jalur inflamasi atau kerentanan genetik, tetapi juga perubahan kekebalan yang terkait dengan penuaan dan aktivasi glia, sebagai akibat dari cedera saraf (Herrero et al., 2015).

Spirulina adalah pelindung saraf dalam model hemiparkinsonisme yang diinduksi 6OHDA. Spirulina memberikan efek antiinflamasi dan aktivitas antioksidan yang kuat (Lima et al., 2017). Phycocyanin adalah pigmen berwarna biru dan biliprotein memiliki khasiat kuat sebagai antioksidan dan antiinflamasi (Izadi \& Fazilati, 2018). Ekstrak lainnya yaitu Epipremnum aureum telah dieksplorasi memiliki beberapa aktivitas farmakologis seperti antibakteri, antiinflamasi, antijamur, antioksidan, dll (Meshram \& Srivastava, 2015). Hasil penelitian menunjukkan bahwa ekstrak etanol daun E. aureum memiliki efek pelindung saraf terhadap ROT, dengan demikian mengurangi gejala motorik seperti hipokinesia, kekakuan, dan ketidakstabilan postur tubuh (Sood et al., 2020).

\subsection{Aktivitas antiapoptosis}

Ekstrak daun Ginkgo biloba (GB) memiliki sifat antiparkinson terhadap model eksperimen in vitro dan in vivo yang diinduksi MPTP dan diinjeksikan ke dalam substansia nigra. Hasil penelitian menunjukan bahwa ginkgetin, biflavonoid yang diekstrak dari daun GB, dapat memberikan perlindungan yang signifikan terhadap kerusakan sel yang diinduksi 1methyl-4-phenylpyridinium $\left(\mathrm{MPP}^{+}\right)$secara in vitro, menurunkan kadar ROS intraseluler dan mempertahankan potensi membran mitokondria. Selain itu, hasil penelitian menunjukkan bahwa ginkgetin menghambat penurunan ekspresi tyrosine hydroxylase $(\mathrm{TH})$ di SNpc dan aktivitas SOD di striatum, yang pada akhirnya mencegah apoptosis sel saraf (Wang et al., 2015b). Pada tikus model PD yang diinduksi reserpin, efeknya terbukti memperbaiki stres oksidatif, disfungsi mitokondria, dan apoptosis di otak (El-Ghazaly et al., 2015). Ekstrak GB dapat meningkatkan aktivitas lokomotor dan menghambat perkembangan PD pada tikus transgenik $\alpha$-synuclein A53T (Kuang et al., 2018). Coptis chinensis merupakan herbal yang banyak digunakan dalam pengobatan tradisional Tiongkok yang secara signifikan memiliki efek pelindung saraf dengan cara meningkatkan fungsi mitokondria, meningkatkan viabilitas sel, stabilnya konsentrasi ATP intraseluler dan pencegahan terhadap apoptosis sel saraf pada tikus yang diinduksi $\mathrm{MPP}^{+}$dan MPTP (Friedemann et al., 2016).

Oleuropein dari daun zaitun merupakan pelindung saraf pada cedera iskemia atau reperfusi serebral fokal pada tikus (Yu et al., 2016), dan juga sebagai agen perlindungan 
terhadap apoptosis sel saraf (Dekanski et al., 2011). Hasil studi menunjukkan bahwa hewan yang menerima oleuropein memiliki lebih banyak sel dopaminergik dibandingkan dengan kelompok ROT, yang menunjukkan bahwa konsumsi oleuropein melindungi sel dopaminergik terhadap apoptosis yang diinduksi ROT (Sarbishegi et al., 2018). Ekstrak herbal lainnya yaitu ekstrak methanol daun Hibiscus asper memiliki aktivitas pelindung saraf terhadap toksisitas yang diinduksi 6-OHDA melalui aktivitas antioksidan dan antiapoptosis dalam model PD (Hritcu et al., 2011). Ekstrak H. perforatum telah diuji pada tikus yang diinduksi 6-OHDA. Fragmen DNA diukur menggunakan kit ELISA sebagai indikator kematian sel (apoptosis) (Morroni et al., 2013). Efek perlindungan saraf ekstrak hidroalkohol $H$. perforatum dalam model PD dibuktikan melalui pelemahan fragmentasi DNA, astrogliosis, peradangan, dan stres oksidatif (Kiasalari et al., 2016).

\section{Kesimpulan}

Hasil studi telah membuktikan peran ekstrak tanaman herbal dalam melindungi berbagai paparan neurotoksisistas melalui beberapa jalur yang berhubungan dengan PD diantaranya aktivitas antioksidan, aktivitas antiinflamasi, dan aktivitas antiapoptosis. Ekstrak tanaman herbal mampu meningkatkan perilaku motorik, meningkatkan kadar dopamin, meminimalkan agregasi $\alpha$-synuclein, memperbaiki stres oksidatif, disfungsi mitokondria, dan juga apoptosis di otak. Bukti-bukti yang ada menjadikan ekstrak tanaman tersebut sebagai calon obat potensial yang kuat dalam terapi pencegahan atau pengobatan PD. Penelitian lebih lanjut perlu dilakukan untuk memahami mekanisme pelindung saraf dalam pengobatan yang efektif untuk PD.

\section{Daftar pustaka}

Ablat, N., Lv, D., Ren, R., Xiaokaiti, Y., Ma, X., Zhao, X., Sun, Y., Lei, H., Xu, J., Ma, Y., Qi, X., Ye, M., $\mathrm{Xu}, \mathrm{F} ., \mathrm{Han}, \mathrm{H} ., \mathrm{\&} \mathrm{Pu}, \mathrm{X}$. (2016). Neuroprotective effects of a standardized flavonoid extract from safflower against a rotenone-induced rat model of Parkinson's disease. Molecules, 21(9). doi:10.3390/molecules21091107

Abushouk, A.I., Negida, A., Ahmed, H., \& Abdel-Daim, M.M. (2017). Neuroprotective mechanisms of plant extracts against MPTP induced neurotoxicity: Future applications in Parkinson's disease. Biomed Pharmacother, 85, 635-645.

Adi, Y.K., Widayanti, R., \& Pangestiningsih, T.W. (2018). n-Propanol extract of boiled and fermented koro benguk (Mucuna pruriens seed) shows a neuroprotective effect in paraquat dichloride-induced Parkinson's disease rat model. Vet World, 11(9), 12501254. 
Ahn, S., Song, T.J., Park, S.U., Jeon, S., Kim, J., Oh, J.Y., Jang, J., Hong, S., Song, M.A., Shin, H.S., Jung, Y.R., \& Park, H.J. (2017). Effects of a combination treatment of KD5040 and (L)-dopa in a mouse model of Parkinson's disease. BMC Complement Altern Med, 17(1), 220. doi:10.1186/s12906-017-1731-2

Albarracin, S.L., Stab, B., Casas, Z., Sutachan, J.J., Samudio, I., Gonzalez, J., Gonzalo, L., Capani, F., Morales, L., \& Barreto, G.E. (2012). Effects of natural antioxidants in neurodegenerative disease. Nutr Neurosci, 15(1), 1-9.

Ardhianta, I.R., Peranginangin, J.M., \& Handayani, S. (2019). Aktivitas antiparkinson ekstrak rosella (Hibiscus sabbdariffa L.) pada tikus putih jantan (Rattus norvegicus) galur Sprague Dawley yang diinduksi haloperidol. Jurnal Farmasi Indonesia, 14(2), 160-168.

Bais, S., Gill, N.S., \& Kumar, N. (2015). Neuroprotective effect of Juniperus communis on chlorpromazine induced Parkinson disease in animal model. Chinese Journal of Biology, 2015, 1-7. doi:10.1155/2015/542542

Bhangale, J.O., \& Acharya, S.R. (2016). Anti-Parkinson activity of petroleum ether extract of Ficus religiosa (L.) leaves. Adv Pharmacol Sci, 2016. doi:10.1155/2016/9436106

Bi, Y., Qu, P.C., Wang, Q.S., Zheng, L., Liu, H.L., Luo, R., Chen, X.Q., Ba, Y.Y., Wu, X., \& Yang, H. (2015). Neuroprotective effects of alkaloids from Piper longum in a MPTP-induced mouse model of Parkinson's disease. Pharm Biol, 53(10), 1516-1524.

Blandini, F. (2013). Neural and immune mechanisms in the pathogenesis of Parkinson's disease. J Neuroimmune Pharmacol, 8(1), 189-201.

Blesa, J., Phani, S., Jackson-Lewis, V., \& Przedborski, S. (2012). Classic and new animal models of Parkinson's disease. J Biomed Biotechnol, 2012. doi:10.1155/2012/845618

Chandrakesan, A., Muruhan, S., \& Sayanam, R. (2018). Morin inhibiting photocarcinogenesis by targeting ultraviolet-B-induced oxidative stress and inflammatory cytokines expression in Swiss Albino Mice. International Journal of Nutrition, Pharmacology, Neurological Diseases, 8(2), 41-46.

da Costa, I.M., Cavalcanti, J., de Queiroz, D.B., de Azevedo, E.P., do Rêgo, A.C.M., Filho, I.A., Parente, P., Botelho, M.A., \& Guzen, F.P. (2017). Supplementation with herbal extracts to promote behavioral and neuroprotective effects in experimental models of Parkinson's disease: A systematic review. Phytother Res, 31(7), 959-970.

Dekanski, D., Selaković, V., Piperski, V., Radulović, Z., Korenić, A., \& Radenović, L. (2011). Protective effect of olive leaf extract on hippocampal injury induced by transient global cerebral ischemia and reperfusion in Mongolian gerbils. Phytomedicine, 18(13), 1137-1143.

Du, T., Li, L., Song, N., Xie, J., \& Jiang, H. (2010). Rosmarinic acid antagonized 1-methyl-4phenylpyridinium (MPP+)-induced neurotoxicity in MES23.5 dopaminergic cells. Int J Toxicol, 29(6), 625-633.

El-Ghazaly, M.A., Sadik, N.A., Rashed, E.R., \& Abd-El-Fattah, A.A. (2015). Neuroprotective effect of EGb761® and low-dose whole-body $\gamma$-irradiation in a rat model of Parkinson's disease. Toxicol Ind Health, 31(12), 1128-1143.

Essa, M.M., Braidy, N., Bridge, W., Subash, S., Manivasagam, T., Vijayan, R.K., Al-Adawi, S., \& Guillemin, G.J. (2014). Review of natural products on Parkinson's disease pathology. $J$ Aging Res Clin Pract, 3(3), (127-136.

Friedemann, T., Ying, Y., Wang, W., Kramer, E.R., Schumacher, U., Fei, J., \& Schröder, S. (2016). Neuroprotective effect of Coptis chinensis in MPP and MPTP-induced Parkinson's disease models. Am J Chin Med, 44(5), 907-925.

Giri, M.A., Bhalke, R.D., Prakash, K.V., \& Kasture, S.B. (2020). Antiparkinsonian and antioxidant effects of hydroalcoholic extract of Camellia sinensis, Asparagus racemosus, Mucuna 
pruriens and their combination. International Journal of Pharmaceutical Investigation, 10(4), 569-574.

Herrero, M.T., Estrada, C., Maatouk, L., \& Vyas, S. (2015). Inflammation in Parkinson's disease: role of glucocorticoids. Front Neuroanat, 9, 32. doi:10.3389/fnana.2015.00032

Hritcu, L., Foyet, H.S., Stefan, M., Mihasan, M., Asongalem, A.E., \& Kamtchouing, P. (2011). Neuroprotective effect of the methanolic extract of Hibiscus asper leaves in 6hydroxydopamine-lesioned rat model of Parkinson's disease. J Ethnopharmacol, 137(1), 585-591.

Izadi, M., \& Fazilati, M. (2018). Extraction and purification of phycocyanin from Spirulina platensis and evaluating its antioxidant and anti- inflammatory activity. Asian Journal of Green Chemistry, 2(2). doi: 10.22034/ajgc.2018.63597

Jacquet, A.d.R., Ambaw, A., Tambe, M.A., Ma, S.Y., Timmers, M., Grace, M.H., Wu, Q., Simon, J.E., McCabe, G.P., Lila, M.A., Shi, R., \& Rochet, J. (2021). Neuroprotective mechanisms of red clover and soy isoflavones in Parkinson's disease models. bioRxiv, 1-43. doi:10.1101/2020.12.01.391268

Jayanthi, P., \& Vijayalakshmi, K.M. (2018). Comparative molecular docking studies and structural prediction of plant compounds on lrrk2. International Journal of Pharmaceutical Sciences and Research, 9(6), 2258-2265.

Kabra, A., Baghel, U.S., Hano, C., Martins, N., Khalid, M., \& Sharma, R. (2020). Neuroprotective potential of Myrica esulenta in haloperidol induced Parkinson's disease. J Ayurveda Integr Med, 11(4), 448-454.

Kasture, S., Mohan, M., \& Kasture, V. (2013). Mucuna pruriens seeds in treatment of Parkinson's disease: Pharmacological review. Oriental Pharmacy and Experimental Medicine, 13. doi:10.1007/s13596-013-0126-2

Khotimah, H., Ali, M., Sumitro, S.B., \& Widodo, M.A. (2015). Decreasing $\alpha$-synuclein aggregation by methanolic extract of Centella asiatica in zebrafish Parkinson's model. Asian Pacific Journal of Tropical Biomedicine, 5(11), 948-954.

Kiasalari, Z., Baluchnejadmojarad, T., \& Roghani, M. (2016). Hypericum perforatum hydroalcoholic extract mitigates motor dysfunction and is neuroprotective in intrastriatal 6-hydroxydopamine rat model of Parkinson's disease. Cell Mol Neurobiol, $36(4), 521-530$.

Kim, T.H., Cho, K.H., Jung, W.S., \& Lee, M.S. (2012). Herbal medicines for Parkinson's disease: a systematic review of randomized controlled trials. PLoS One, 7(5), 1-10.

Klivenyi, P., \& Vescei, L. (2011). Molecular neurodegeneration. Molecular Neurodegeneration, 6(1), 6. doi:https://doi.org/10.1007/978-1-61779-328-8

Kuang, S., Yang, L., Rao, Z., Zhong, Z., Li, J., Zhong, H., Dai, L., \& Tang, X. (2018). Effects of Ginkgo biloba extract on A53T $\alpha$-synuclein transgenic mouse models of Parkinson's disease. Can J Neurol Sci, 45(2), 182-187.

Li, J., Long, X., Hu, J., Bi, J., Zhou, T., Guo, X., Han, C., Huang, J., Wang, T., Xiong, N., \& Lin, Z. (2019). Multiple pathways for natural product treatment of Parkinson's disease: A mini review. Phytomedicine, 60. doi:https://doi.org/10.1016/j.phymed.2019.152954

Li, X.Z., Zhang, S.N., Liu, S.M., \& Lu, F. (2013). Recent advances in herbal medicines treating Parkinson's disease. Fitoterapia, 84, 273-285. doi:10.1016/j.fitote.2012.12.009

Lieu, C.A., Venkiteswaran, K., Gilmour, T.P., Rao, A.N., Petticoffer, A.C., Gilbert, E.V., Deogaonkar, M., Manyam, B.V., \& Subramanian, T. (2012). The antiparkinsonian and antidyskinetic mechanisms of Mucuna pruriens in the MPTP-treated nonhuman primate. Evid Based Complement Alternat Med, 2012. doi:10.1155/2012/840247 
Lima, F.A.V., Joventino, I.P., Joventino, F.P., de Almeida, A.C., Neves, K.R.T., do Carmo, M.R., Leal, L., de Andrade, G.M., \& Viana, G.S.d.B. (2017). Neuroprotective Activities of Spirulina platensis in the 6-OHDA Model of Parkinson's Disease Are Related to Its AntiInflammatory Effects. Neurochem Res, 42(12). doi:10.1007/s11064-017-2379-5

Marsh, L. (2013). Depression and Parkinson's disease: current knowledge. Curr Neurol Neurosci Rep, 13(12), 409. doi:10.1007/s11910-013-0409-5

Marumoto, K., Yokoyama, K., Inoue, T., Yamamoto, H., Kawami, Y., Nakatani, A., Fukazawa, Y., Hosoe, Y., Yamasaki, A., \& Domen, K. (2019). Inpatient Enhanced Multidisciplinary Care Effects on the Quality of Life for Parkinson Disease: A Quasi-Randomized Controlled Trial. Journal of geriatric psychiatry and neurology, 32(4), 186-194.

Meshram, A., \& Srivastava, N. (2015). Epipremnum aureum (Jade pothos): A multipurpose plant with its medicinal and pharmacological properties. Journal of Critical Reviews, 2 (2), 21-25.

Morroni, F., Tarozzi, A., Sita, G., Bolondi, C., Zolezzi Moraga, J.M., Cantelli-Forti, G., \& Hrelia, P. (2013). Neuroprotective effect of sulforaphane in 6-hydroxydopamine-lesioned mouse model of Parkinson's disease. Neurotoxicology, 36, 63-71. doi:10.1016/j.neuro.2013.03.004

Mouchaileh, N., \& Hughes, A.J. (2020). Pharmacological management of Parkinson's disease in older people. Journal of Pharmacy Practice and Research, 50(5), 445-454.

Oliveira, A.I., Pinho, C., Sarmento, B., \& Dias, A.C. (2016). Neuroprotective activity of Hypericum perforatum and its major components. Front Plant Sci, 7, 1-15. doi:10.3389/fpls.2016.01004

Pinto, N.B., da Silva Alexandre, B., Neves, K.R., Silva, A.H., Leal, L.K., \& Viana, G.S. (2015). Neuroprotective properties of the standardized sxtract from Camellia sinensis (green tea) and its main bioactive components, Epicatechin and Epigallocatechin gallate, in the 6-OHDA model of Parkinson's disease. Evid Based Complement Alternat Med, 2015. doi:10.1155/2015/161092

Pringsheim, T., Jette, N., Frolkis, A., \& Steeves, T.D. (2014). The prevalence of Parkinson's disease: a systematic review and meta-analysis. Mov Disord, 29(13), 1583-1590.

Ren, R., Shi, C., Cao, J., Sun, Y., Zhao, X., Guo, Y., Wang, C., Lei, H., Jiang, H., Ablat, N., Xu, J., Li, W., Ma, Y., Xianrong, Q., Ye, M., Pu, X., \& Han, H. (2016). Neuroprotective effects of a standardized flavonoid extract of safflower against neurotoxin-induced cellular and animal models of Parkinson's disease. Scientific Reports, 6, 1-13. doi:10.1038/srep22135

Sandhu, K.S., \& Rana, A.C. (2013). Evaluation of Anti Parkinson's activity of Nigella sativa (Kalonji) seeds in chlorpromazineinduced experimental animal model. International Journal of Pharmacy and Pharmaceutical Sciences, 5, 884-888.

Sarbishegi, M., Charkhat Gorgich, E.A., Khajavi, O., Komeili, G., \& Salimi, S. (2018). The neuroprotective effects of hydro-alcoholic extract of olive (Olea europaea L.) leaf on rotenone-induced Parkinson's disease in rat. Metab Brain Dis, 33(1), 79-88.

Segura-Aguilar, J., Paris, I., Muñoz, P., Ferrari, E., Zecca, L., \& Zucca, F.A. (2014). Protective and toxic roles of dopamine in Parkinson's disease. J Neurochem, 129(6), 898-915.

Song, J.X., Sze, S.C.W., Ng, T.B., Lee, C.K.F., Leung, G.P.H., Shaw, P.C., Tong, Y., \& Zhang, Y.B. (2012). Anti-Parkinsonian drug discovery from herbal medicines: What have we got from neurotoxic models? Journal of Ethnopharmacology, 139(3), 698. doi:10.1016/j.jep.2011.12.030 
Sood, S., Kumar, M., Bansal, N., \& Garrido, G. (2020). Ethanol extract of Epipremnum aureum leaves attenuate intranigral-rotenone induced Parkinson's disease in rats. Journal of Pharmacy \& Pharmacognosy Research, 8, 225-236.

Suliman, N.A., Taib, C.N.M., Moklas, M.A.M., Adenan, M.I., Baharuldin, M.T.H., \& Basir, R. (2016). Establishing natural nootropics: recent molecular enhancement influenced by natural nootropic. Evid Based Complement Alternat Med, 2016. doi:10.1155/2016/4391375

Teerapattarakan, N., Benya-Aphikul, H., Tansawat, R., Wanakhachornkrai, O., Tantisira, M.H., \& Rodsiri, R. (2018). Neuroprotective effect of a standardized extract of Centella asiatica ECa233 in rotenone-induced parkinsonism rats. Phytomedicine, 44, 65-73. doi:10.1016/j.phymed.2018.04.028

Tjay, T., \& Rahardja, K. (2015). Obat-Obat Penting (7 ed.): Elex Media Komputindo Kompas Gramedia.

Wang, Q., Liu, Y., \& Zhou, J. (2015a). Neuroinflammation in Parkinson's disease and its potential as therapeutic target. Transl Neurodegener, 4(1), 1-9.

Wang, Y.Q., Wang, M.Y., Fu, X.R., Peng, Y., Gao, G.F., Fan, Y.M., Duan, X.L., Zhao, B.L., Chang, Y.Z., \& Shi, Z.H. $\left(2015^{\mathrm{b}}\right)$. Neuroprotective effects of ginkgetin against neuroinjury in Parkinson's disease model induced by MPTP via chelating iron. Free Radic Res, 49(9), 1069-1080.

Yadav, S., Rai, S., \& Singh, S. (2016). Mucuna pruriens shows neuroprotective effect by inhibiting apoptotic pathways of dopaminergic neurons in the Paraquat mouse model of Parkinsonism. EUROPEAN JOURNAL OF PHARMACEUTICAL AND MEDICAL RESEARCH, 3.

Youssef, S.B., Brisson, G., Doucet-Beaupré, H., Castonguay, A.M., Gora, C., Amri, M., \& Lévesque, M. (2021). Neuroprotective benefits of grape seed and skin extract in a mouse model of Parkinson's disease. Nutr Neurosci, 24(3), 197-211.

Yu, H., Liu, P., Tang, H., Jing, J., Lv, X., Chen, L., Jiang, L., Xu, J., \& Li, J. (2016). Oleuropein, a natural extract from plants, offers neuroprotection in focal cerebral ischemia/reperfusion injury in mice. Eur $J$ Pharmacol, 775, 113-119. doi:10.1016/j.ejphar.2016.02.027

Zhang, F., Lu, J., Zhang, J. G., \& Xie, J. X. (2015). Protective effects of a polysaccharide from Spirulina platensis on dopaminergic neurons in an MPTP-induced Parkinson's disease model in C57BL/6J mice. Neural Regen Res, 10(2), 308-313.

Zhang, H., Bai, L., He, J., Zhong, L., Duan, X., Ouyang, L., Zhu, Y., Wang, T., Zhang, Y., \& Shi, J. (2017). Recent advances in discovery and development of natural products as source for anti-Parkinson's disease lead compounds. Eur J Med Chem, 141, 257-272. doi:10.1016/j.ejmech.2017.09.068

Zheng, M., Chen, M., Liu, C., Fan, Y., \& Shi, D. (2021). Alkaloids extracted from Uncaria rhynchophylla demonstrate neuroprotective effects in MPTP-induced experimental parkinsonism by regulating the PI3K/Akt/mTOR signaling pathway. $J$ Ethnopharmacol, 266. doi:10.1016/j.jep.2020.113451 